\title{
Contested Fields I: Race and Ethnicity
}

Contemporary Asatru as a whole is an ethnic tradition, largely stemming from the interest in recovering a forgotten heritage, and our forebears placed great weight on matters of kin and clan [while] prohibit[ing] racism of any sort. ${ }^{1}$

This somewhat anachronistic statement, which suggests that pre-Christian Nordic peoples prohibited racism, can be found in Our Troth, the two-volume self-presentation of North American a-racist Asatru. It indicates a dilemma within Asatru that revolves around the categories of race, ethnicity, culture, tradition, and heritage, and their relation to spirituality. The controversies and schisms deriving from this quandary are interesting for three reasons: Firstly, they are an integral part of the path toward respectability Asatru has taken. Secondly, they point to the acute self-consciousness of contemporary Asatruers regarding the racist implications of their faith. Lastly, they are connected to the shifting significance of relations between culture, ethnicity, and religion, i.e., to processes of "neo-ethnification"2 that have structured discussions on immigration and integration in the Western world over the past twenty years. In this chapter, we will examine these disagreements and ruptures, and consider how they are intertwined with mainstream discourses on ethnicity.

\section{Asatru and National Socialism}

From the outside, Asatru is time and again equated across the board with neo-Nazis and völkisch-Ariosophic concepts. Asatru is thus constantly in a defensive position and has to face up to the challenge of actively proving its own innocence, so to speak, daily. ${ }^{3}$

1 Gundarsson, Our Troth, vol. II, 31.

2 Marianne Gullestad, Plausible Prejudice. Everyday Experiences and Social Images of Nation, Culture and Race (Oslo: Universitetsforlaget, 2006).

3 Correspondence with Kurt Oertel (Eldaring): "Asatru [wird] von außen [...] immer wieder pauschal mit Neo-Nazis und völkisch-ariosophischen Konzepten gleichgesetzt. Dadurch befindet sich Asatru in einer konstanten Verteidigungsstellung und muss sich quasi täglich erneut der Herausforderung einer aktiven Beweisführung der eigenen Unschuld stellen.”

(C) KONINKLIJKE BRILL NV, LEIDEN, 2016 | DOI 10.1163/9789004309517_006

This is an open-access article distributed under the terms of the Creative Commons Attribution-

NonCommercial 3.o. Unported (CC BY-NC 3.o) License, http://creativecommons.org/licenses/by-nc/3.0/ 9789004309517 
With these words, a German a-racist Asatruer justifies the need to dissociate from National Socialism and racism. According to him, such an automatic association is caused by an uninformed public, in whose eyes the use of Norse deities and symbols such as the Thorshammer, the Irminsul, and the runes not to mention the swastika - have been associated with National Socialist ideology and propaganda. Furthermore, a number of white supremacist groups claim that their political agenda has to be realized through the belief in the 'ancestral religion' of the 'white race,' the 'Aryans' or 'Germanic peoples.' This forces Asatruers to distance themselves from overtly racist interpretations of their faith. ${ }^{4}$ The common association between 'the Germanic' and National Socialism has led the vast majority of Asatruers after 1945, even racial-religious ones, ${ }^{5}$ to at least superficially distance themselves and their religion from National Socialism. In 1984, Adolf Schleipfer, leader of the racial-religious Armanen-Orden, emphasized that the idea of a German empire, as well as the cult of a Führer, stood in stark contrast to the values of the Armanen-Orden. According to him, it was time the world finally acknowledged

that the Germanic and Armanism have absolutely nothing to do with violence, dictatorship, fascism, oppression, concentration camps, war mongering, etc.! That such prejudices are nothing but propaganda meant to veil the 'grand plan of the anonymous' for the annihilation of the Germanic! This is anti-Germanism in its highest power! ${ }^{6}$

As mentioned, especially in Germany, my own publications have at times been perceived as generalizing condemnations of Asatru. This has to be taken into consideration, as my interview partners of course reacted to this perception.

4 There are two reasons this has become all the more necessary: Firstly, a number of books in the 1990 s and 200os, e.g. by Jeffrey Kaplan, Mattias Gardell, and myself, have brought to light the overt and, in some cases, more hidden and implicitly racist, anti-Semitic, or white supremacist agendas of such groups. Secondly, more recently established Asatru groups have taken a stance against racist tendencies within Heathenism, cf. Kaplan, Radical Religion in America, Gardell, Gods of the Blood, Schnurbein, Religion als Kulturkritik, Göttertrost in Wendezeiten.

5 Only the most overtly religious National Socialist organizations, such as the Gylfiliten in Germany, who counted Hitler amongst their deities (cf. Religion als Kulturkritik, 174), and some of the American white supremacist Odinist groups investigated by Mattias Gardell, Gods of the Blood, refer unambiguously positively to National Socialism.

6 Quoted from Schnurbein, Religion als Kulturkritik, 72: "daß Germanentum und Armanentum nichts, aber auch garnichts mit Gewalt, Diktatur, Faschismus, Unterdrückung, Kz's, Kriegshetze usw. zu tun hat! Daß solche Vorurteile nichts als Propaganda sind und den großen Plan der Anonymen' zur Vernichtung des Germanentums verschleiern sollen! Dies ist Antigermanismus in höchster Potenz!" 
In fact, this quote does not reveal an anti-National Socialist attitude, but rather an anti-Semitic one. The "grand plan of the anonymous" alludes to the Armanen-Orden's conviction that Jews and Christians are behind a world conspiracy encompassing the churches, communism, socialism, liberalism, capitalism, Masonic orders etc., all of which are considered "international exploiters, destroyers of Volk and nature."

American Asatru author and occultist Stephen Flowers/Edred Thorsson makes a structurally similar argument, pointing to more concealed anti-Semitic and anti-Masonic implications. ${ }^{8}$ He blames the idea that the modern Norse revival and National Socialism are closely related on a specific genre of popular occult literature dealing with National Socialism, which sees the roots of National Socialism in an all-embracing occult conspiracy. ${ }^{9}$ Flowers turns to an

7 Ibid., 70. "Internationale Ausbeuter, Volks- und Naturzerstörer."

8 Cf. his introduction to The Secret King, a book about Heinrich Himmler's alleged magician Karl Maria Wiligut (alias Weisthor). (Flowers and Moynihan, The Secret King. The Myth and Reality of Nazi Occultism) Wiligut claimed to have access to ancestral or racial memory in a similar way as Guido List did, but set his idea of an "Irminic" Christianity in competition to List's Armanist system. Schnurbein, Religion als Kulturkritik, 113-115.

9 For example Louis Pauwels and Jacques Bergier, The Morning of the Magicians (London: Mayflower, 1971), Trevor Ravenscroft, The Spear of Destiny (London: Samuel Weiser, 1972). Pauwels/Bergier's and Ravenscroft's works have had considerable influence on the spread of an esoteric Hitlerism. Their theories rely partially on an account by Rudolf Glauer (alias Rudolf von Sebottendorf, 1875-1945), a cosmopolitan adventurer and spy who combined List's teachings with the Islamic mysticism he had encountered on his travels to Turkey and Egypt. In 1918, he founded the lodge Thule-Gesellschaft (Thule Society). The Thule Society seems to be one of the few völkisch religious and Ariosophic associations that for a time attracted leading National Socialists, such as Dietrich Eckart, Rudolf Heß, and Alfred Rosenberg as guests or members. In 1934, Sebottendorf published a book under the sensational title Bevor Hitler kam (Before Hitler Came) where he stylized himself and his Thule Society as the most important precursors of National Socialism. This publication was not well received by Hitler and the National Socialist establishment, who were eager to demonstrate respectability and thus denied all connections with occultist activities. Sebottendorf's essay was certainly highly unreliable as a historical source and unfounded in most of its claims. However, it became the main source not only for Pauwels, Bergier, and Ravenscroft, but also earlier writers, such as the anthroposophist Joachim Besser, "Die Vorgeschichte des Nationalsozialismus im neuen Licht," Die Pforte 2 (1950) and Dietrich Bronder, Bevor Hitler kam. Eine historische Studie, 2. expanded ed. (Geneva: Pfeiffer, 1975). For a recent thorough repudiation of theories about occult influences within National Socialism, cf. Ulrich Linse, "Der Chiemsee-Goldkessel - ein völkisch-religiöses Kultobjekt aus der NS-Zeit? The State of the Affairs," in Die völkisch-religiöse Bewegung im Nationalsozialismus. Eine Beziehungs- und Konfliktgeschichte, ed. Uwe Puschner and Clemens Vollnhals (Göttingen: Vandenhoeck \& Ruprecht, 2012). 
anti-capitalist counter-theory of conspiracy. According to him, the anti-Nazis who depicted National Socialism as a demonic, occult endeavor had their own occult agenda in which high-ranking politicians, in particular Winston Churchill, were involved. Flowers goes on to claim that the "Freemason" Churchill believed the true grail would manifest itself "as a global form of finance capital." This belief was supposedly Churchill's motivation in fighting German National Socialism, which was "dedicated to the abolition of usury."10 Flowers' emphasis on Churchill's involvement with Masonry and his implicit reference (through the loaded term "usury") to Jews, insinuates that these forces might somehow be responsible the occult anti-Nazi propaganda. At the same time, Flowers/Thorsson puts himself into the tradition of völkisch occultism by publishing books about and by Ariosophists. For him, National Socialist and ss symbolism contain a "great and dark historical significance, whose cause is now intelligible only to those who have the ability to see beyond good and evil to extract the Noble even from that which is base in the eyes of the mob."11

In spite of the fact that Flowers/Thorsson and his Rune Gild enjoy a good reputation in large parts of current a-racist Asatru, such veiled anti-Semitic statements have become rare in Asatru. It has instead become more common to ascribe the evils of National Socialism, including its anti-Semitism, to Christian patterns. Whereas protagonists of the völkisch religious movement tended to reject Christianity because of its Jewish roots, many a-racist Asatruers take the opposite stance, condemning anti-Semitism by pointing to its origin in Christianity. In 1972, the Icelandic Ásatrúarmenn argued successfully against allegations of being racist and National Socialist by stating that National Socialism was not a Neopagan movement, but closely allied with the Christian churches. ${ }^{12}$ Géza von Neményi, of the ethnicist German Germanische Glaubensgemeinschaft, claims that both anti-Semitism and National Socialist ideology are based in Christian thought. This allows him to downplay the racist foundations of his own historical forerunners, such as Ludwig Fahrenkrog. ${ }^{13}$

10 All quotes Flowers and Moynihan, The Secret King. The Myth and Reality of Nazi Occultism, $22 f$.

11 He goes on to argue that "its symbolic quality has little [...] to do with the political aims of National Socialism, or with its criminal behavior," and he maintains that the forms it used remain "fascinating and worthwhile," cf. Edred, History of the Rune-Gild, III (The Reawakening of the Gild 1980-2005), 90. The quoted passages refer to a "magical Working" of Edred Thorsson and Michael Aquino from the Temple of Set at the ss castle Wewelsburg, where Aquino gave Thorsson an ss dagger - an act that Thorsson interprets as "one of the most powerful rites of passage in the Germanic world - the sword taking." (ibid., 89).

12 Pétursson, Asasamfundet på Island och massmedia, 185:1, 7-12.

13 Géza v. Neményi, Heidentum und Ns-Ideologie (Werbig: Germanische Glaubensgemeinschaft, 1997). 
The ethnicist German $V f g H$ also sees a "monotheistic-dualistic configuration" at the basis of völkisch religiosity and thus salvages modern Asatru from the association with both. ${ }^{14}$ Our Troth aligns the völkisch Germanic mysticism and National Socialism with the Christian enemy, in this case the medieval Christian mission in the North. It thus exculpates itself, or rather, the roots of 'one's native tradition'. It describes "German Mysticism and the Nazi Perversion of the Faith"15 as the result of a mix of medieval anti-Judaism, Darwinism, and nationalism, considering it the "greatest harm Germanic religion and culture have suffered since the [...] eleventh century,"16 i.e., the era of Christianization in Iceland. By referring to the medieval Christian roots of anti-Semitism and (incorrectly) claiming that it was exclusively a German phenomenon that did not exist in Scandinavia, the author isolates a continental 'perverted' tradition of a Germanic revival. He posits it against a good, untainted English and Scandinavian tradition of interest in Nordic myth in the 19th and 2oth centuries, but fails to mention how entangled these movements are and the common roots and interests that they share.

The fact that the a-racist German Eldaring initially sought the proximity of exactly these Anglo-American and Scandinavian traditions in order to mark its own distance from the tainted German völkisch mysticism demonstrates how effectively the topos of a 'harmless' Nordic revival and its German/Nazi (and Christian) perversion has been employed. The treatment of Alexander Rud Mills in Our Troth is a similar attempt at distinguishing a 'good' Anglo-Saxon from a 'bad' continental tradition. Although Mill's anti-Semitic tendencies are acknowledged, his involvement with National Socialism is largely ignored. He comes across as a person prosecuted mainly for his faith and not for his National Socialist politics and anti-Semitic ideology. ${ }^{17}$

We can draw three preliminary conclusions:

1. The identification of Asatru with National Socialist thought is a problem Asatruers cannot avoid.

2. Asatruers frequently try to evade this problem by aligning National Socialism and racial mysticism with what they perceiveas theirmainenemy, Christianity. In this way, they cast themselves as the 'good' minority persecuted by authoritarian forces such as National Socialism or Christian churches.

\footnotetext{
14 Anonymous, "'Gott in uns.' Völkische Religiosität in Deutschland," Ringhorn. Gemeinschaftsanzeiger des Vereins für germanisches Heidentum e.V. 41 (2004). The anonymous author here quotes Henning Eichberg, a protagonist of the German New Right.

15 Gundarsson, Our Troth, vol. I, 99.

16 Ibid., vol. I, 101.

17 Ibid., vol. I, 106.
} 
3. It is reductionist to narrow all that is problematic with racial or ethnicist thinking to National Socialist ideology. This is equally true from the opposite perspective. Rejecting Asatru as a racist cult because of its alleged proximity to National Socialism, or explaining National Socialism through alleged Neopagan or occult origins, does not hold up to scrutiny either. ${ }^{18}$ Rather, the concepts of ethnicity and cultural heritage employed in Asatru hark back to National Romantic and völkisch traditions that seem to surface in modern Western societies on a regular basis, giving rise to the various waves of ethnification in public discourse.

\section{The 'Folkish' Versus 'Universalist' Controversy}

Within Asatru, the affiliation of ethnicist positions with völkisch right-wing extremist ideas has been the cause of many heated debates. The most internationally high-profile debate has raged since the 1990 os between the so-called 'universalists' and the 'folkish' faction in the USA, and has spread to other countries as well. It revolves around the question of who should have access to Asatru. While the folkish faction (represented by members of the $A F A$ as well as the Asatru Alliance) maintains that Asatru is the native religion for people with 'Germanic' ancestry, and that it should remain exclusive to them, the universalists (represented by members of The Troth) insist the religion should remain open for everyone drawn to it. Such a clear distinction is difficult to uphold even on an empirical level. A number of influential Asatruers ${ }^{19}$ have been involved in both folkish groups and The Troth and contributed considerably to shaping the latter's worldview without this causing any major disruption. Outspokenly folkish groups have occasionally admitted members of 'non-Germanic' heritage, ${ }^{20}$ while even the most inclusive universalist groups acknowledge that they do not have significantly more members with

18 Such a thesis was most prominently advanced by Wilfried Daim, Der Mann der Hitler die Ideen gab. Jörg Lanz von Liebenfels (first edition 1958) who considered Jörg Lanz von Liebensfels “The Man who Gave Hitler his Ideas." To my knowledge there are few scholars who have taken that route in recent years. One of them, Peter Kratz, Die Götter des New Age, identifies the New Age movement with fascism, the other Karla Poewe, New Religions and the Nazis, greatly exaggerates Jakob Wilhelm Hauer's and his German Faith Movement's influence on Hitler and his followers.

19 This is, for example, the case for William Bainbridge, who has been a member of both The Troth and the Asatru Alliance. cf. Kaplan, Radical Religion in America, 21. Also leading Theodists' active involvement with The Troth makes the distinction tenuous.

20 Cf. examples in Strmiska and Sigurvinsson, "Asatru: Nordic Paganism in Iceland and America" and Gundarsson, Our Troth, vol. II, 27. 
non-European backgrounds than the exclusive, folkish groups. At the same time, the distinction between ethnic and cultural criteria remains unclear. While universalist Asatruers often include ideas about ethnic specificities into their faith, folkish concepts occasionally emphasize cultural difference over ethnic. ${ }^{21}$ Differing attitudes regarding the role of genetics, heritage and ancestry cannot be dichotomized easily; rather, they structure a diverse and frequently contradictory spectrum of positions within and beyond Asatru.

Only racial-religious groups with an outspokenly white supremacist or Aryanist agenda, such as Vigrid in Norway, the Armanen-Orden in Germany, or the ones investigated by Gardell claim that Asatru is a religion based mainly or even exclusively on race. ${ }^{22}$ These groups tend to consider the gods as racial archetypes and turn race itself into a religious category. In this way, they justify the superiority of the 'white,' 'Aryan,' or 'Nordic' race and religion, and argue that conserving the race is a religious act and thus an aim in itself. Even in such openly racist groups, race is never conceptualized as an exclusively biological category, but a spiritual and cultural one as well. This was already true for the völkisch movement and völkisch religion of the late 19th and early 2oth century, which, as Uwe Puschner and others have shown, initially rejected a purely biological-racial anti-Semitism as a reductive simplification. Nevertheless, völkisch ideology was firmly based on a cultural and religious anti-Semitism and a 'positive Aryanism. ${ }^{23}$ Even the more biologistic concepts, which had an increased influence on völkisch religious thought after 1900, relied on the perception of race as a spiritual or cultural category. The same is true for the racial theories of Anglo-Saxonism. "There was never any sharp separation between a precise scientific racialism and literary racial nationalism."24 Distinguishing between racial-religious and ethnicist groups is a matter of degree, not of principle. Both insist that genetic heritage, cultural tradition, and religion form an indistinguishable unity, and that Asatru is therefore the naturally inherited religion of all people of 'Germanic' ancestry.

American Asatruer Stephen McNallen has frequently laid claim to a

middle ground on racial issues. On the one hand we were proud of our European heritage, and we actively espoused the interests of Europeandescended people. On the other hand we opposed totalitarianism and

\footnotetext{
21 Cf. Gründer, Blótgemeinschaften, 88, who calls attention to these borderline phenomena, but maintains that the dichotomy 'folkish - universalist' remains an important factor for the self-understanding of differences in Asatru.

22 Gardell, Gods of the Blood.

23 Puschner, Die Völkische Bewegung im wilhelminischen Deutschland, 54, 71-76.

24 Horsman, Race and Manifest Destiny, 159.
} 
racial hatred, convinced that decency and honor required us to treat individuals of all racial groups with respect. ${ }^{25}$

In the early 1980s, McNallen came forward with a scientific-metaphysical theory explaining how biology and spirituality are organically intertwined. This theory of "metagenetics" has made him one of the most controversial Asatruers worldwide. Basing his arguments on Jungian psychology and studies on "reincarnation memories" 26 - which he assumes are recollections coded in the DNA - he comes to the conclusion that "Asatru is the expression of the soul of our race."27 In a revision of his thoughts in 1999, he elaborates:

Our religion is a function of who we are, not just what we believe. Since the human being is a holistic entity, our spirituality cannot be considered something apart from our physical ancestry. In terms of both genetics and metagenetics, our ancestors are encoded into our very beings. [...] It seems reasonable, then, to predict that people will tend to be most fulfilled by the religious and spiritual paths of their ancestors. [...] The beliefs of our ancestors are largely confirmed by modern psychology and the biological sciences. Most especially, the Jungian collective unconscious and Sheldrake's hypotheses concerning 'morphic field' and 'morphic resonance' are very close to the Germanic ideas surrounding the Well of Urth, in which orlog or 'fate' is laid. ${ }^{28}$

McNallen's need to revisit his concept in 1999 indicates the impact his provisional reflections have had among Asatruers. ${ }^{29}$

25 McNallen, "Three Decades of the Ásatú Revival in America," 208, cf. Kaplan, Radical Religion in America.

26 This concept closely resembles the idea of an ancestral memory as was put forward by Guido von List.

27 Stephen A. McNallen, "Metagenetics," Asatru Folk Assembly, http://www.runestone.org/ index.php?option=com_content $\&$ view $=$ article $\&$ id $=143$ : metagenetics\&catid=82:articles \&Itemid=571, last accessed January 12, 2015. Cf. Gardell, Gods of the Blood, 270.

28 Stephen A. McNallen, "Genetics \& Beyond. Metagenetics - An Update," The Runestone 26 (1999). The article is also available online: http://www.runestone.org/index.php?option =com_content\&view=article\&id=144:genetics-a-beyond-metagenetics-an-update\&catid $=82$ :articles\&Itemid $=571$, last accessed January 12, 2015 .

29 Most groups and individuals who are convinced of a biological dimension of their religion at some point refer to McNallen. See also the discussion of metagenetics in Gundarsson, Our Troth, vol. II, 31-37. 
McNallen and the majority of 'folkish' Asatruers are careful to distinguish themselves from radical racists who claim superiority of their 'folk' or 'race' and its right to subdue other 'races,' a position only the most radical white supremacist Odinists would hold today. However, they make it quite clear that they deem it necessary to keep one's race or tradition as pure as possible. Individuals of non-European backgrounds are thus not welcome in Asatru, and individuals of mixed heritage are considered a grave problem. ${ }^{30}$ McNallen even revised his earlier infatuation with the Vikings on these grounds, arguing that they were cosmopolitan and "incorporated a mass of non-native elements." ${ }^{31}$

The question of a relation between race and spirituality also surfaces in European groups. Like McNallen and other ethnicist Asatruers, German Géza von Neményi rejects the idea of a unified 'white race,' instead relying on older theories about various European races, such as the 'Nordic,' the 'Faelic,' and the 'Ostic,' etc. He maintains that race differences are a fact, "albeit unpopular." Moreover, he narrows the definition of racism to apply only to an overt hierarchization of races, stressing defensively that the exclusion of nonGermanic persons does not imply a degradation of others, but ensures "a kind of religious self-actualization of the Germanics." 32 The argument that racism only pertains to active discrimination and that differentialism and separatism are 'non-racist' also arose in the aforementioned controversy surrounding Stephen McNallen's invitation to the International Asatru Summer Camp in 2009. Those opposing his invitation considered the rhetoric around race and heritage displayed on the $A F A$ 's website a breach of their own antiracist statutes. Danish supporters explained this disagreement by pointing to different definitions of racism: In Denmark, they claim, the term 'racism' is used to describe the assumption of racial superiority only, while Norwegians and Swedes allegedly consider the categorization of humans into races as

30 Cf. for example Gardell, Gods of the Blood, $270 \mathrm{of}$.

31 McNallen, "Three Decades of the Ásatú Revival in America," 216. In his e-mail newsletter AFA update, McNallen occasionally quotes from blogs on the anti-immigration website vdare.com, cf. AFA update 1-5-11. In 2002, he served as the president of the European American Issues Forum, an organization that describes itself as a civil rights and activist organization working on behalf of people of European heritage and warns of 'reverse racism' against whites, cf. for example Adrienne Sanders, "Group Claims White Victims," San Francisco Examiner, June 05, 2002.

"eine Art religiöser Selbstverwirklichung der Germanen," Neményi, Heidentum und NSIdeologie, 3 f. The article is also available online: http://allsherjargode.beepworld.de/ heidentum-und-ns.htm, last accessed March 26, 2014. 
racist in and of itself. ${ }^{33}$ The turmoil was partly motivated by concerns around attracting unwanted media attention, although statements made by some of the groups, who were clearly deeply upset, indicate that it was more than just the fear of stigma from negative press that motivated these European Asatruers (along with members of The Troth in the USA) to adopt a broader definition of racism and to perceive all racial categorization as unscientific and based on prejudice. ${ }^{34}$ One Asatru critic of McNallen's metagenetics writes that, instead of offering "an explanatory rendering of the interface between history, the body, ethnicity, and religion," it is nothing but a "totalizing narrative that attempts to seal the borders and protect itself from contamination from the Other." 35

Such a stance has also been taken by Edred Thorsson/Stephen Flowers, who rejects the idea that Germanic culture was ever static or 'pure.' He modified the metagenetic paradigm accordingly, considering its exclusive focus on biological heritage reductive and suggested looking not just at 'ethnic culture' but also at 'ethical,' 'material,' and 'linguistic' culture, as well as their constant interaction with one another. According to Flowers, they need to be reintegrated "into an organic and vital whole in which the individual will stand as a culturally authentic man." ${ }^{36}$ This model seems less exclusionary and static, but still maintains that physical, biological heritage plays an important role in spiritual traditions. ${ }^{37}$ It mirrors Romantic and völkisch ideals of a holistic unity of ethnicity, language, culture, and spirituality that reaches into a deep past. It reaffirms the significance of biological heritage by emphasizing that

The body contains a code which bears the essential story of all of one's ancestors. One's cultural myths articulate these, and these myths are re-encoded in actual tales expressed in often archaic languages.

33 The controversy is documented in Danish Forn Siðr's journal Vølse 47, March 2009.

34 Cf. Gundarsson, Our Troth, vol. II, 35-37, as well as Asfrid, “Warum Asatru?" Ringhorn. Gemeinschaftsanzeiger des Vereins für germanisches Heidentum e.V. 48 (2006), and Interview F, with a German Asatruer, May 2010, Germany; Interview D, with a German Asatruer, March 2010, Germany.

35 Garadyn McOisdealbhaigh, "Metagenetics: The Fear of Penetration and the Penetration of Fear," Irminsul Ættir, http://www.irminsul.org/arc/oo8gm.html, last accessed January $12,2015$.

36 Stephen Edred Flowers, "The Idea of Integral Culture. A Model for a Revolt Against the Modern World," Tyr. Myth - Culture - Tradition 1 (2002), 11.

Ibid., 13 . 
Consequently, the rediscovery of Norse sources and their employment in cultural and religious contexts constitutes a "whole cultural reawakening of dormant or vestigial patterns." 38

\section{An 'Ethnic Religion of Nature'?}

Both a-racist and some ethnicist Asatruers who reject genetic paradigms feel that the term 'ethnic religion' or 'ethnic nature religion' avoids the problem, and is thus better suited to describing their faith. We have to ask whether or not this is a mere strategic shift of terminology. In other words: When is 'ethnicity' to be understood as a euphemized replacement for the stigmatized term 'race,' and when, if at all, does it in fact denote something qualitatively different?

Danish Asatruer Grølheim emphasizes that 'nature religion' not only refers to a faith which sees nature as animated or divine, but also to its 'natural' evolution. He continues:

By far the most naturally developed religions are simultaneously ethnic religions. [...] It is undoubtedly correct that most of us have chosen Asatru because it is the root of our ethnic identity.39

Grølheim uses 'ethnic' in much the same way as 'folkish' Asatruers in America would, but he avoids addressing the question of genetic heritage. Forn Siðr officially distances itself from the idea of genetic heritage by stressing "we consider all humans equal. [....] Everybody with a sincere interest in Asatru is welcome independent of descent/form/color." At the same time they admit to a certain form of "ethnocentrism" in "our tradition." ${ }^{40}$ Nevertheless, both Grølheim and Forn Siðr are in agreement with ethnicist Asatru when it comes to defining an ethnic group or 'folk' not as a nation, but as a smaller entity. In contrast to the Us, Danish Asatruers tie ethnicity closely to a territory, to the "area where it originated and therefore usually is suited to the people who live there." ${ }^{41}$

\footnotetext{
38 All quotes ibid., 16.

39 "Det er utvivlsomt rigtigt at de fleste af os har valgt Asetroen fordi den er roden til vores etniske identitet." Grølheim, "Mangfoldighed og tolerance," Vølse 11 (200o), 16.

40 "Man kan selvfølgelig ikke se bort fra det etnocentriske i vores overleveringer," FAQ Forn Siðr (http://fornsidr.dk/om-forn-sidr/spoergsmaal-og-svar\#Nationalisme, last accessed March 26, 2014).

41 Ibid.
} 
This idea of a relation between territory and people is shared by German $V f g H$, the group which has elaborated the concept of Asatru as an 'ethnic nature religion' the farthest. Their definition reads as follows:

Germanic Paganism is the religion of the gods who are in the nature of Northern and Central Europe and who live in all beings and things this nature has created.

Germanic Paganism is the religion of the historical Germanic peoples and their culture. It does not make the claim to be valid worldwide and it does not mission.

Germanic Paganism is the religion of today's people who are members of a Germanic community by birth or association and who feel obliged to their heritage. ${ }^{42}$

Here, the idea of a unity between culture, heritage, descent, and nature is foregrounded and tied indissolubly to deities, myth, and cultic practice, so that religion comes to define a people or Volk in much the same way as National Romanticism has:

A Volk in the traditional sense of 'ethnos,' 'gens,' and 'diot' is an association with common gods and cultures who others do not share. A native religion is a constitutive characteristic of a Volk, and vice versa, the Volk is a constitutive characteristic of religion. [...] Völker in this sense, which is also the traditional Pagan one, are founded mythically. [...] In myth that forms the foundation for a Volk, that Volk recognizes itself - and always, when people recognize themselves together in a myth, they become a Volk. ${ }^{43}$

"Allgemeine Konzepte des VfgH im Überblick" (www.vfgh.de, last accessed March 26, 2014): "Das germanische Heidentum ist die Religion der Götter, die in der Natur Nord- und Mitteleuropas sind und in allen Wesen und Dingen leben, die diese Natur hervorgebracht hat. Das germanische Heidentum ist die Religion der historischen germanischen Völker und ihrer Kultur. Es erhebt keinen Anspruch auf weltweite Gültigkeit und missioniert nicht. Das germanische Heidentum ist die Religion heutiger Menschen, die durch Geburt oder Aufnahme Angehörige einer germanischen Gemeinschaft sind und sich ihrem Erbe verpflichtet fühlen."

43 "Die Religionen der 'Völker," Ringhorn. Gemeinschaftsanzeiger des Vereins für germanisches Heidentum e.V. 41 (2004), 3f: “Ein Volk im traditionellen Sinn von 'ethnos,' 'gens,' und 'diot' ist ein Verband mit gemeinsamen Göttern und Kulturen, die andere nicht haben. Die eigene Religion ist ein konstitutierendes Merkmal für ein Volk, und umgekehrt ist das Volk ein konstituierendes Merkmal von Religion. [...] Völker in diesem Sinn, der 
Accordingly, several members of the $V f g H$ feel sympathetic toward the AFA and Stephen McNallen's attempts at 'folk-building,' although the majority would still reject the (meta)genetic approach as too narrow. ${ }^{44}$ Fritz Steinbock's/ Asfrid's writings illustrate well the ambivalences and contradictions implicated in this approach. Steinbock, the author of several books on Heathenism, is considered the guiding theorist of the $\mathrm{VfgH}$, and frequently points out the pitfalls of overly simplistic and straightforward presumptions about cultural and religious continuity. Nevertheless, his point of departure is the assumption of a unity of gods, nature, and men, from which language and culture have developed. ${ }^{45} \mathrm{He}$ considers a genetically 'pure' 'Germanic' ancestry a potentially dangerous fiction, and goes on to salvage the concept of ancestry and heritage in two ways. Firstly, he claims that anybody can be considered an ancestor, if they contributed to

creating what is common to us, what defines our common identity: Language, culture, history, the homeland (Heimat) which they cultivated and helped to create, and not least the religion, which for us Heathens probably is the most important heritage of the ancestors that we succeed to. [...] Ancestors are the ones whose heritage we succeed to. ${ }^{46}$

Secondly, he makes ancestry into a matter of active choice, of conscious construction, which remains necessary, however, for the creation of a "stable" and "unambiguous identity":

We are not in every way and not exclusively heirs of the Teutons (Germanen), but an interplay of factors identify us fundamentally as their heirs so that contradictions seem less important. It becomes indeed

auch der traditionell heidnische ist, sind mythisch begründet.[...] Im Mythos, der ein Volk begründet, erkennt es sich selbst - und immer dann, wenn sich Menschen gemeinsam in einem Mythos erkennen, werden sie zu einem Volk."

An exception is $V f g H$ member Stilkam, who published translations of the two articles by McNallen on his (now defunct) homepage "Stilkams Seiten." The German articles were also printed in the magazine Schwarz\&Magisch (No.1, 2005).

45 Steinbock, Das heilige Fest, 222.

46 " $[. .$.$] denn sie haben all das geschaffen, was uns gemeinsam ist und unsere gemeinsame$ Identität bestimmt: Sprache, Kultur, Geschichte, die von ihnen bebaute und mitgestaltete Heimat und nicht zuletzt die Religion, die für uns Heiden das wohl wichtigste Erbe der Ahnen ist, das wir antreten. [...] Ahnen sind diejenigen, deren Erbe wir antreten." Asfrid, "Ahnen," Ringhorn. Gemeinschaftsanzeiger des Vereins für germanisches Heidentum e.V. 42 (2004), 3 . 
unsubstantial when such a search for identity has the consequence that we pay more attention to the heritage we consider more substantial. Heritage becomes that which we appropriate consciously, and after which we form ourselves. Thus, the Teutons become all the more 'our ancestors' the more we consider them as such and the more we want to come into their inheritance. ${ }^{47}$

This quote shows again how potential contradictions within such views are avoided in order to maintain the goal of recovering a Heathen religious tradition, which should remain unmixed and unadulterated by foreign elements in spite of evidence to the contrary. ${ }^{48}$ On the basis of such implicitly problematic claims, Hans Schuhmacher, from the German Rabenclan, has classified Steinbock's construction of an ethnic religion of nature, as outlined in his book Das Heilige Fest (The Sacred Feast), as a version of an ethno-pluralist ideology. 49

\section{Ethno-pluralism and the European New Right}

The term 'ethno-pluralism' emerged in the 1980 s in discussions within the European radical Right, and owes much to the Romantic Herderian concept of Volk (see Chapter 1).50 It conceptualizes ethnic communities as

47 Ibid., 5: "Wir sind nicht in allem und nicht ausschließlich Erben der Germanen, aber ein Zusammenspiel von Faktoren weist uns wesentlich als ihre Erben aus und lässt Widersprüchliches unwesentlich erscheinen. Es wird dann auch in der Tat unwesentlich, wenn die Folge einer solchen Identitätsfindung ist, dass wir dem als wesentlich erachteten Erbe größere Aufmerksamkeit schenken. Es wird dasjenige, das wir uns bewußt aneignen und nach dem wir uns formen. So werden die Germanen umso mehr 'unsere Ahnen,' je mehr wir sie als solche betrachten und ihr Erbe antreten wollen."

48 Steinbock, Das heilige Fest, 6of.

49 Cf. Hans Schuhmacher, “Das Heilige Fest' - ein Grundlagenwerk?” Rabenclan e.V., www .rabenclan.de/index.php/Magazin/HansSchuhmacherDasheiligeFest3, last accessed January 21, 2015.

50 It was initially suggested by Henning Eichberg, a German sport sociologist now residing in Denmark, who at the time identified as a national revolutionary and a member of the New Right. Eichberg has been a member of both left-wing and right-wing organizations in Germany and Denmark. He has promoted a 'third way' of bridging the differences between the left and the right through a revolutionary liberation nationalism, cf. Claudia Globisch, “'Deutschland uns Deutschen, Türkei den Türken, Israelis raus aus Palästina.' Ethnopluralismus und sein Verhältnis zum Antisemitismus," in Die Dynamik der 
homogenous cultural entities bound to, and formed by, a specific territory or nature, and by a common cultural heritage with roots in a deep past. Under ideal conditions, such communities should remain homogenous and identical; they are not overtly hierarchized, rather considered 'different but equal.' Any kind of mixing or migration is considered detrimental to the formation of stable identities and thus to peaceful co-existence. Due to its essentialist view of culture as deeply rooted in tradition and landscape and immutable in its fundamental essence - rather than a meeting place of constantly changing and evolving ideas, mentalities, and practices - the concept bears strong similarities to racist thought. However, ethno-pluralism performs a shift from a primarily biological paradigm to a cultural one. ${ }^{51}$ It has therefore been aptly described as a 'new racism,' 'cultural racism,' or 'differentialist racism,' i.e., an ideology that serves the same purpose as racism, while avoiding the stigmatized term 'race.' 52

The scattered movement constituting the European New Right goes back to an initiative in the late 196os centering around the French philosopher Alain de Benoist and his organization GRECE (Groupement de recherche et d'études pour la civilisation européenne - Research and Study Group for European Civilization). ${ }^{53}$ In Germany, a heterogenous network of groups, journals, and publishers took up these activities, among them Pierre Krebs' cultural organization Thule Seminar, as well as cultural-political journals such as Nation \& Europa (which Henning Eichberg wrote for) and Junge Freiheit (Young Freedom). The New Right fashioned itself as a reaction against the leftist ideas of 1968. It adopted political strategies and tools from the New Left in order to instigate a 'culture war' (Kulturkampf) from the right. These strategies were directed against all international, universalist, capitalist, and socialist forces that allegedly threatened the ethnic substance of European identity by

europäischen Rechten. Geschichte, Kontinuitäten, Wandel, ed. Claudia Globisch, Agnieszka Pufelska, and Volker Weiß (Wiesbaden: vs Verlag, 2011), 207.

$5^{1}$ Considering the fact that 'traditional' versions of racism also never relied on exclusively biological paradigms, but always resorted to cultural or spiritual notions, this shift is certainly not absolute. In recent public discussions, at least in Germany, biological or genetic arguments have resurfaced as well.

$5^{2}$ Cf. Balibar, "Is there a 'New Racism'?" as well as Pierre-André Taguieff, La Force du préjugé. Essai sur le racisme et ses doubles (Paris: La Découverte, 1988) (Engl. translation The Force of Prejudice. On Racism and its Doubles (Minneapolis: University of Minnesota Press, 2001)).

53 For recent English language analyses of the European New Right see Tamir Bar-On, Where Have all the Fascists Gone? (Aldershot-Hamshire: Ashgate, 2007) and Roger Woods, Germany's New Right as Culture and Politics (London: Palgrave Macmillan, 2007). 
imposing a "vodka-cola imperialism."54 From Antonio Gramsci, Benoist borrowed the concept of cultural hegemony and the goal of influencing the ideological and cultural superstructure in order to eventually gain political power. The concept of ethno-pluralism contributes to this meta-political strategy. In contrast to the traditional extreme right, the New Right is not necessarily antidemocratic, nor does it usually promote authoritarian or autocratic forms of government. ${ }^{55}$ However, it perceives democracy as a matter of ethnic homogeneity by claiming that natural organic collectives are the only appropriate expression of a people's will. It rejects representational and parliamentary systems as undemocratic because they impede the immediacy of a direct influence of the Volk - hence the critical term 'ethnocracy' for such concepts. ${ }^{56}$

In our context, it is important to note that exponents of the French New Right, Benoist in particular, already relied heavily on Herder's cultural relativist notions of a homogenous Volk, and traced his ideas back to German Conservative and National Revolutionaries. ${ }^{57}$ From this tradition, Benoist derived his anti-Christian attitude and philosophical Paganism. It is driven by a rejection of Marxism, liberalism, and the idea of universal human rights. Moreover, Benoist sees the roots of these universalist ideas in the JudeoChristian tradition, against which he sets Indo-European mentality and

54 Michael Minkenberg, Die neue radikale Rechte im Vergleich. USA, Frankreich, Deutschland (Opladen/Wiesbaden: Westdeutscher Verlag, 1998), 152f.

"Die radikale Rechte in Europa heute. Profile und Trends in Ost und West," in Die Dynamik der europäischen Rechten. Geschichte, Kontinuitäten, Wandel, ed. Claudia Globisch, Agnieszka Pufelska, and Volker Weiß (Wiesbaden: vs Verlag, 2011), 117.

$5^{6}$ Cf. Globisch, "Deutschland uns Deutschen, Türkei den Türken, Israelis raus aus Palästina," 211f. In a recent interview (Robert Scholz and Mathias Brodkorb, "Über Habitus, Ideologie und Praxis. Im Gespräch mit Henning Eichberg," Endstation Rechts, http:// www.endstation-rechts.de/index.php?option=com_k2\&view=item\&id=4971, last accessed November 11, 2011), Eichberg describes his journey from the (German) right to the (Danish) left in terms that mirror this privileging of the Volk. He describes the orientation towards Europe he found in the New Right as an expression of a fascist totalitarianism, because it took its relation to power as a starting point. Focusing on the Volk instead means a necessary turn towards democracies. One could also describe this move as a turn from a statist right to a Romantic right. Cf. Diedrich Diederichsen, "Der Anarch, der Solitär und die Revolte. Rechte Poststrukturalismus-Rezeption in der BRD," in Rechtsextremismus. Ideologie und Gewalt, ed. Richard Faber, Hajo Funke, and Gerhard Schoenberner (Berlin: Edition Hentrich, 1995), 241.

57 Cf. most recently Globisch, "Deutschland uns Deutschen, Türkei den Türken, Israelis raus aus Palästina," 20gf. See also Minkenberg, Die neue radikale Rechte im Vergleich. USA, Frankreich, Deutschland, 141f, 152, 161 as well as "Die radikale Rechte in Europa heute. Profile und Trends in Ost und West." 
culture. Like his forerunners in the Conservative Revolution, along with C.G. Jung and Mircea Eliade, from whom he drew inspiration, Benoist's Paganism - although philosophical in nature and not meant as a call for a literal revival of a Pagan religion - led to an increased value being placed on myth. Myth is seen as a privileged access to the deep essentials of each culture, i.e., its archetypal roots. ${ }^{58}$ While Benoist's Paganism led to the political marginalization of the New Right in the 1990s, ${ }^{59}$ it offers a welcome philosophical framework to ethnicist Asatruers who have found it relevant and adaptable to their concepts of ethnic religion.

The reception of New Right thought within Asatru started in Germany in the mid-1980s. Harry Radegeis (alias Harry Schmidt), a member of the racialreligious Armanen-Orden and activist of the extreme right, called for a change of direction from the old authoritarian right to the new National Revolutionary right within Pagan political activism. Demonstrating clearly the strategic purpose behind this shift, Radegeis wrote:

Go to the grassroots! Work with the Greens, Alternatives, National Revolutionaries, etc. Contribute there with your knowledge! [...] That would be true progress! That would confuse the enemy! For then he would no longer know where to look for us and how to survey us. ${ }^{60}$

In recent years, the circles around Stephen Flowers' Rune Gild and Stephen McNallen's ethnicist $A F A$ have actively promoted Benoist's and others' New Right theories. ${ }^{61}$ The AFA offers the English translation of Benoist's Being A Pagan, published by the same press as the journal Tyr, with a preface by Stephen Flowers.

$5^{8}$ Cf. Göran Dahl, "Den 'nya högern' och nyhedendommen," in Myter om det nordiska mellan romantik och politik, ed. Catharina Raudvere, Anders Andrén, and Kristina Jennbert, Vägar till Midgård (Lund: Nordic Academic Press, 2001), 132-134.

59 Minkenberg, Die neue radikale Rechte im Vergleich. USA, Frankreich, Deutschland, 154.

6o Irminsul - Stimme der Armanenschaft 1 (1985). Cf. Schnurbein, Göttertrost in Wendezeiten, 31: "Löst den NPD-Haufen endlich auf! Was Besseres könnte garnicht passieren! Geht in die Basis! Arbeitet bei den Grünen, Alternativen, Nationalrevolutionären usw. mit. Bringt dort euer Wissen ein! [...] Das wäre echter Fortschritt! Das würde den Gegner verwirren! Dann wüßte er nicht mehr, wo er uns suchen soll und wie überwachen."

61 Flowers has been working on two related book projects, one about "The European New Right and its Meaning for America” another one about "The Pagan Right." See "About the Contributors" in: Tyr II (2003-2004), 415. 


\section{Cultural Essentialism beyond the New Right}

Considering the turn of terminology from racism to cultural essentialism, the claim that ideas such as the ones promoted by the German $\mathrm{VfgH}$ resemble an ethno-pluralist paradigm is justified. They do not emphasize genetic ancestry as foundational for an ethnic religion, but for an organic cultural heritage. Potential associations with New Right or racial-biological essentialist ideologies are the reason why a-racist Asatru groups reject the epithet 'ethnic.' Nevertheless, the majority remains convinced that the intimate intertwining of cultural traditions with the surrounding natural world is the foundation of Asatru - a unity which is perceived as natural and immediate to people who grew up in the respective area and culture. However, as Egil Stenseth of Norwegian a-racist Bifrost asserts, in much the same way as Fritz Steinbock of the ethnicist $V f g H$, it can be appropriated and learned by people with different heritages and cultural backgrounds as well. ${ }^{62}$

Most European Asatruers, regardless of their political convictions, thus base their faith on a sentiment of rootedness and belonging, of the familiar and known, which is tied to landscape as well as childhood memories of stories and songs. The feeling of immediacy is probably strongest in Scandinavia, where it is reinforced by the fact that Eddic myth and medieval literature have been considered integral and unquestioned parts of the national heritage since the 19th century. In countries such as Iceland and Norway, this sense of a national cultural heritage is also closely tied to images of wildlife. Here, the sense of Asatru being rooted in nature, which allegedly has been part of pre-Christian worship for centuries, becomes all the more self-evident. Such ideas of an 'organic culture' permeate Asatru on all levels. Furthermore, Fredrik Gregorius' argument that "concepts tied to cultural identity are often used to avoid touching questions which are related to ethnicity" 63 is valid for more than just Swedish Asatru. ${ }^{64}$

62 Stenseth, "Nyhedendom i Norge." The implications of such views are discussed further in Chapter 6.

63 "att begrepp kopplade till kulturell identitet många gånger används för att undvika att beröra frågor som har med entnicitet at göra." Gregorius, Modern Asatro, 132.

64 Following the publication of Gregorius' book, many Swedish Asatruers have taken exception to this claim, asserting that they have problems finding their own attitudes towards culture and ethnicity in a generalizing statement like this. Instead, they emphasize the aspect of new creation on the basis of tradition (see, for example, Interview W, with a Swedish Asatruer, August 2010). However, even the most adamant and articulate critics of an ethnic perspective, such as Egil Stenseth of Norwegian Bifrost, accentuate that the basis of Asatru could be called ethnic, although the main focus today should be to build something new on this basis, so that the 'doing' of Asatru, i.e. the blot, is at its center, instead of ideology. Cf. Stenseth, "Nyhedendom i Norge," 19. 
The idea of an immediate connection between culture and nature is neither 'natural' nor self-explanatory. We have to understand it as a recurrence or transformation of the Romantic Herderian idea of an organic unity of people, landscape, climate, language, history, and myth. The fact that it seems self-evident to many Asatruers, and that it can be used effectively as a strategy of justification also indicates that the idea is part of a broader cultural consensus. In today's globalized society, cultural essentialism and the conflation of the categories 'religion,' 'culture,' 'ethnicity,' and 'race' thrive once again. In one interview, a female Danish Asatruer in her thirties, who perceives herself as a-racist, exemplified the contradictions inherent in such a paradigm. She first rejected the idea of a racial Asatru and a 'pure' heritage, but later maintained that she can easily relate to the concept of an Aryan race. She went on to say that she sees conflicts as taking place not between races, but between religions, a position that in her view is all too often confused with racism. In another part of the interview, it became clear that she sees Islam, which she considers a patriarchal, authoritarian religion, as the main antagonist. Immediately afterwards, she talked about Islam as a "culture that wants to take my freedom away" [my emphasis]. ${ }^{65}$

This example does not reflect values and judgments promoted specifically by any Asatru organization. Instead, it represents a widespread attitude in current Danish society ${ }^{66}$ applied by an Asatruer to explain her religious attitude. It is a trend that extends well beyond Denmark and has been astutely analyzed by Norwegian anthropologist Marianne Gullestad in her writings about the new "integralist ideologies" in Europe. Gullestad observes that "the anti-racist pact among the general public in Europe after Nazism and World War II seems to be slowly and imperceptibly eroded, and that arguments and ideas from former times," especially a "longing for the warmth of an ethnically-based Gemeinschaft" (community), ${ }^{67}$ are "reappearing in new forms." ${ }^{\prime 8}$ Gullestad speaks of a process of 'neo-ethnification', asserting that

65 "en kultur [...], der vil tage min frihed fra mig." Interview H, with a Danish Asatruer, April 2010, Denmark.

66 Cf. for example the contributions in Jørgen S. Nielsen, ed. Islam in Denmark. The Challenge of Diversity (Lanham etc.: Lexington Books, 2010).

67 Gullestad here uses the German term Gemeinschaft as a reference to German sociologist Ferdinand Tönnies' distinction between Gemeinschaft (community) and Gesellschaft (civil society). For Tönnies, Gemeinschaft is an organic form of society based on emotions of belonging, which he distinguishes from the modern, technical, rational, contract-based civil society. This distinction has played a significant role for the self-understanding of corporatist movements, alternative communities, and nationalist movements in Germany in the first part of the 2oth century. For a translation of Tönnies' 1887 work see Ferdinand Tönnies, Community and Civil Society (Cambridge University Press, 2001). 
the concept of 'ethnification,' with its focus on "specific ideas about language, culture, descent and territory," is "recombined in new ways in the face of extraEuropean immigration." ${ }^{69}$ These "categories, rhetorical strategies, and points of view formerly regarded as extremist" are aggressively promoted by populist right-wing politicians all over Europe. At the same time, they have by now turned into much more deeply ingrained "signs which circulate" and are regarded as "a form of self-evident conventional wisdom." 70 One of the effects is to replace or veil social class or economic inequality as valid categories of social conflict and to mask, as well as implicitly reaffirm, existing privilege. ${ }^{71}$

While Asatru in many ways has moderated and reflected its own roots in and attitudes toward racial and ethnicist ideologies, the European mainstream itself has taken a turn toward culturalist or cultural essentialist thought. Both trends are responsible for the fact that the majority of Asatruers today can no longer be found in radical right-wing environments. Asatru fashions itself as an alternative religion that sides with other allegedly suppressed religions and ethnic cultures. At the same time, it finds increasing support in mainstream ideologies, at least with regard to its views on culture and cultural roots. Heathens connect their ideas about culture, heritage, and religion with the political discussions in their respective countries. A case in point is the difference between Swedish and Danish Asatru regarding some Asatruers' attitude toward immigrants in general, and Islam in particular. Many Danish Asatruers will quite uninhibitedly set 'our religion' and 'our people' against the 'foreign culture' of Islam. This, however, should not necessarily be read as a sign of Asatru in Denmark having become more ethnicist and anti-Islamist in recent years. Rather, it is a sign that the current anti-Islamic climate in Denmark and the restrictive immigration policy make it possible for Asatruers to voice such attitudes more openly. The opposite is the case in Sweden, which has a more open and integrative immigration policy and has officially embraced the idea of multi-culturalism as an identity marker for modernSweden. Correspondingly, many Swedish Asatruers fashion themselves and their religion as pluralist and multi-culturalist and emphasize the cosmopolitan and diverse nature of Old Norse society, whereas attitudes that betray cultural essentialist stances remain in the background. ${ }^{72}$

\footnotetext{
69 Ibid., 299 .

$70 \quad$ Ibid., 302.

71 Cf. ibid., 307. In this sense, we could speak of a success of the New Right's struggle for cultural hegemony, although it is a success that has not directly benefited the circles that promoted these ideas.

72 This is an argument that Gregorius, Modern Asatro, 132, is making.
} 
The ongoing discussions within and around Asatru about issues of race, ethnicity, and culture have had an opposite effect as well. Some a-racist groups and individuals have in fact developed a heightened awareness of the problems connected with naïve and unreflective assumptions about heritage, ethnicity, cultural tradition, and their relations to religion that reveal a considerable amount of political astuteness and skepticism toward fantasies of origin. Jenny Blain, an anthropologist and member of a-racist The Troth, has noted the danger of possible slippages toward basing religion on concepts of ethnicity and race. They are motivated by the faulty assumptions that the 'peoples' of the past can be identified at all; that their cultures and spiritualities were clearly demarcated and that culture, spirituality, language, and 'race' coincide. While such assumptions are common in Neopaganism, Blain insists that, due to the problematic history of Heathenism, they are more reflected in some Heathen groups than in Neopaganism in general. ${ }^{73}$ In fact, interviews with members of a-racist groups such as Norwegian Bifrost, Swedish Samfundet Forn Sed, and the German Eldaring in particular indicate that Blain has a point. Many Asatruers today see the necessity of criticizing what Ann-Marie Gallagher has called "a whole range of misconceptions, and arguably misappropriations, of concepts of history, nation, 'race,' and ethnicity, which seem to exist within popular Pagan lore."74

Kurt Oertel, the Warden of the Lore in the German Eldaring, cautions:

In the Germanic world, ethnicity wasn't by far as fixed as older models or also some of our contemporaries would like to see. [...] Celts as well as Teutons [Germanen] were not homogeneous peoples [...]. One has to always be clear that the term 'culture' in archaeological language exclusively refers to similarities of ceramic forms, styles of jewelry etc. and it is far from sure whether or not this concept of culture corresponds to the social reality of this era. ${ }^{75}$

\footnotetext{
73 Blain and Wallis, "Heathenry," 423.

74 Anne-Marie Gallagher, "Weaving a Tangled Web? Pagan Ethics and Issues of History, 'Race' and Ethnicity in Pagan Identity," in Handbook of Contemporary Neopaganism, ed. James R. Lewis and Murphy Pizza (Leiden/Boston: Brill, 2009), 577.

75 Kurt Oertel, “Die Angeln. Teil 2: Die neue Heimat," Herdfeuer. Die Zeitschrift des Eldaring e.V. 3, no. 10 (2005), gf: "Ethnizität war in der germanischen Welt keineswegs so festgelegt, wie ältere Modelle und auch noch gewisse Zeitgenossen das gerne hätten. [...] Sowohl Kelten wie auch Germanen waren in sich selbst ja kein jeweils einheitliches Volk [...]. Man muss sich stets darüber klar sein, dass der Begriff 'Kultur' in archäologischem Sprachgebrauch ausschließlich auf Ähnlichkeiten von Keramikformen, Schmuckstilen
} 
Henrik Hallgren, former chair of the Swedish Samfundet Forn Sed (formerly $S A S$ ), also argues against a holistic concept of culture, and for seeing "culture $[\ldots]$ as an open system..76 Others follow Gallagher and insist on asking what attracts so many right-wing groups and individuals to Paganism, and emphasize the importance of making "a positive statement which irrevocably dissociates us from them." ${ }^{77}$ For Egil Stenseth, of Norwegian Bifrost, this means taking a firm political stance against right-wing extremist, racial, and ethnicist thought within Asatru. He points out how a completely 'unpolitical' attitude within Asatru can lead to fierce infighting and splintering in groups whose membership spans the full political spectrum, from far right to far left. ${ }^{78}$ German a-racist Nornirs \& $E t$ directs a similar critique against groups that claim Asatru to be a spiritual way that should be considered separate from politics. For Nornirs Aett, this unreflective and naïve attitude unintentionally opens up the potential for völkisch and right-wing ideologies and individuals to gain influence. For them, the choice of following a 'Nordic' or 'Germanic' spiritual path requires a politically active and critical stance against the völkisch and right-wing tendencies within Asatru. Nornirs \&tt maintain that they feel inspired by Old Norse texts and artefacts along with fictional and Neopagan readings of them. Nonetheless, they perceive culture and community not as reified entities that can be traced back into a (deep) past or even something that already exists, but as something which must be continually created.

We can conclude that Asatru religion is characterized by a tension that is difficult to resolve. On the one hand, there is awareness of the problems connected to racial paradigms and of the fact that modern Asatru has to be based on new constructions of religion. On the other hand, there is a strong desire for wholeness and authenticity, for rootedness. A German Asatruer stresses that "one nevertheless wants to have something like a feeling of continuity," a sense of - and desire for - something "authentic," which can be found in the realm of the archaic. He acknowledges the reality of constant cultural mixing, while insisting on the necessity of having a mythological basis as a "support which integrates a person into his or her environment."79

usw. beruht, und ob dieser Kulturbegriff der damaligen sozialen Realität entsprach, ist keineswegs gesichert."

76 Interview with Henrik Hallgren (Samfundet Forn Sed): "Jag ser kultur mer som ett öppet system."

77 Gallagher, “Weaving a Tangled Web?" 587.

78 Interview with Egil Stenseth (Bifrost).

79 Interview D: "aber, man möchte trotzdem noch zumindest so was wie das Gefühl einer Kontinuität haben. [...] Ich denke, eine Mythologie bindet einen Menschen in seine Umgebung mit ein." 
Summarizing these controversies, we could say that the field of Asatru religion is formed by a tension or oscillation between the search for community, which is often, but not always, conceptualized as culturally homogenous, and the desire to find an expression for one's own spiritual or esoteric preferences, a desire based on a modern liberal individualism. One possible way to reconcile such differences is to attempt to see the values of individualism and personal spirituality not as modern phenomenon, but to conceptualize them as pre-Christian Nordic values.

What this chapter has shown is the persistence of a neo-Romantic conflation of religion, culture, and ethnicity, which is not limited to Asatru, but can be found in Western societies in general - a conflation which could be described as an ethnification or culturalization of religion as well as a sacralization of culture. In her discussion of neo-ethnification and new culturalism in Northern Europe, Marianne Gullestad also mentions in passing the religious aspects of the problem: "Religion, as a repository of traditions of symbols and beliefs, always stands ready to be tapped by those who wish to develop a new framework of ideas about social order." She makes this point in order to demonstrate how "in Norway, the Christian religion, in the form of the Lutheran State Church, has gained renewed importance as an institution uniting even secularized majority Norwegians in opposition to Islam." ${ }^{80}$ While similar arguments could easily be made about the Protestant and Catholic churches in other countries as well, Asatru obviously takes a path diverging from the mainstream in this respect.

8o Gullestad, Plausible Prejudice, 304. 